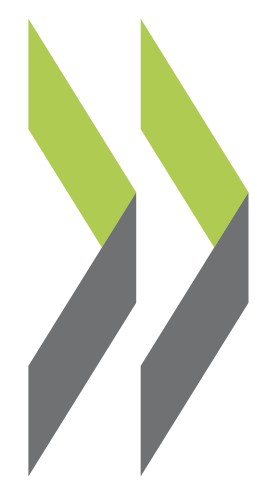

OECD Economics Department Working Papers No. 1335

The Estimation of Financial Conditions Indices
for the Major OECD
Countries
E. Philip Davis, Simon Kirby, James Warren 
Organisation de Coopération et de Développement Économiques

Organisation for Economic Co-operation and Development

10-Oct-2016

ECONOMICS DEPARTMENT

English - Or. English

\section{THE ESTIMATION OF FINANCIAL CONDITIONS INDICES FOR THE MAJOR OECD COUNTRIES}

\section{ECONOMICS DEPARTMENT WORKING PAPERS No. 1335}

By E. Philip Davis, Simon Kirby and James Warren

OECD Working Papers should not be reported as representing the official views of the OECD or of its member countries. The opinions expressed and arguments employed are those of the author $(s)$.

Authorised for publication by Jean-Luc Schneider, Deputy Director, Policy Studies Branch, Economics Department.

All Economics Department Working Papers are available at www.oecd.org/eco/workingpapers

JT03402444

Complete document available on OLIS in its original format

This document and any map included herein are without prejudice to the status of or sovereignty over any territory, to the delimitation of international frontiers and boundaries and to the name of any territory, city or area. 
OECD Working Papers should not be reported as representing the official views of the OECD or of its member countries. The opinions expressed and arguments employed are those of the author(s).

Working Papers describe preliminary results or research in progress by the author(s) and are published to stimulate discussion on a broad range of issues on which the OECD works.

Comments on Working Papers are welcomed, and may be sent to the Economics Department, OECD, 2 rue André-Pascal, 75775 Paris Cedex 16, France, or by e-mail to eco.contact@oecd.org.

All Economics Department Working Papers are available at www.oecd.org/eco/workingpapers.

This document and any map included herein are without prejudice to the status of or sovereignty over any territory, to the delimitation of international frontiers and boundaries and to the name of any territory, city or area.

The statistical data for Israel are supplied by and under the responsibility of the relevant Israeli authorities. The use of such data by the OECD is without prejudice to the status of the Golan Heights, East Jerusalem and Israeli settlements in the West Bank under the terms of international law.

Latvia was not an OECD member at the time of preparation of this publication. Accordingly, Latvia does not appear in the list of OECD Members and is not included in the zone aggregates.

() OECD (2016)

You can copy, download or print OECD content for your own use, and you can include excerpts from OECD publications, databases and multimedia products in your own documents, presentations, blogs, websites and teaching materials, provided that suitable acknowledgment of OECD as source and copyright owner is given. All requests for commercial use and translation rights should be submitted to rights@oecd.org 


\section{Abstract/Résumé \\ The estimation of financial conditions indices for the major OECD countries}

Financial conditions indices (FCIs) have been developed to summarise financial conditions and also supplement more traditional macroeconomic forecasting. They capture market expectations but also quantitative and survey information. This paper seeks to provide up to date financial conditions indices for six countries, France, Germany, Italy, Japan, the United Kingdom and the United States, as well as the euro area, updating earlier results by the OECD. The addition of the period of the financial crisis period has made radical changes to the original results of the FCI estimation. Country-specific estimates provide a number of wrong signs and insignificant coefficients. We find in general that the panel (and NiGEM) based FCIs are more satisfactory. Furthermore, a promising avenue for further research is the dynamic factor/principal components approach.

JEL Classification: E32, E44, E47.

Keywords: Financial conditions index; panel estimation; macro-financial linkages.

$* * * * * * * * * * * * * * * * * * * *$

\section{Estimation des indices des conditions financières pour les grands pays de l'OCDE}

Les indices des conditions financières (ICF) ont été élaborés afin de récapituler les conditions financières et compléter les prévisions macroéconomiques plus classiques. Ils incluent les attentes des marchés mais aussi le traitement des informations quantitatives et les données d'enquêtes. Ce document vise à fournir les ICF les plus récents de six pays: Allemagne, États-Unis, France, Italie, Japon et Royaume-Uni, ainsi que la zone euro, et à actualiser les indices antérieurs établis par l'OCDE. La prise en compte de la période de la crise financière a radicalement modifié les estimations initiales de l'ICF. Les estimations nationales livrent un certain nombre de faux signaux et de coefficients non significatifs. D'une manière générale, nous pensons que les ICF estimés en panel (et à partir du modèle économétrique NiGEM) donnent des résultats plus satisfaisants. En plus, l'analyse des facteurs dynamiques /analyse des composantes principales représentent une approche prometteuse à explorer pour la suite des recherches.

Classification JEL : E32, E44, E47.

Mots clés : indice des conditions financières; estimation en panel; liens macro-financiers. 
TABLE OF CONTENTS

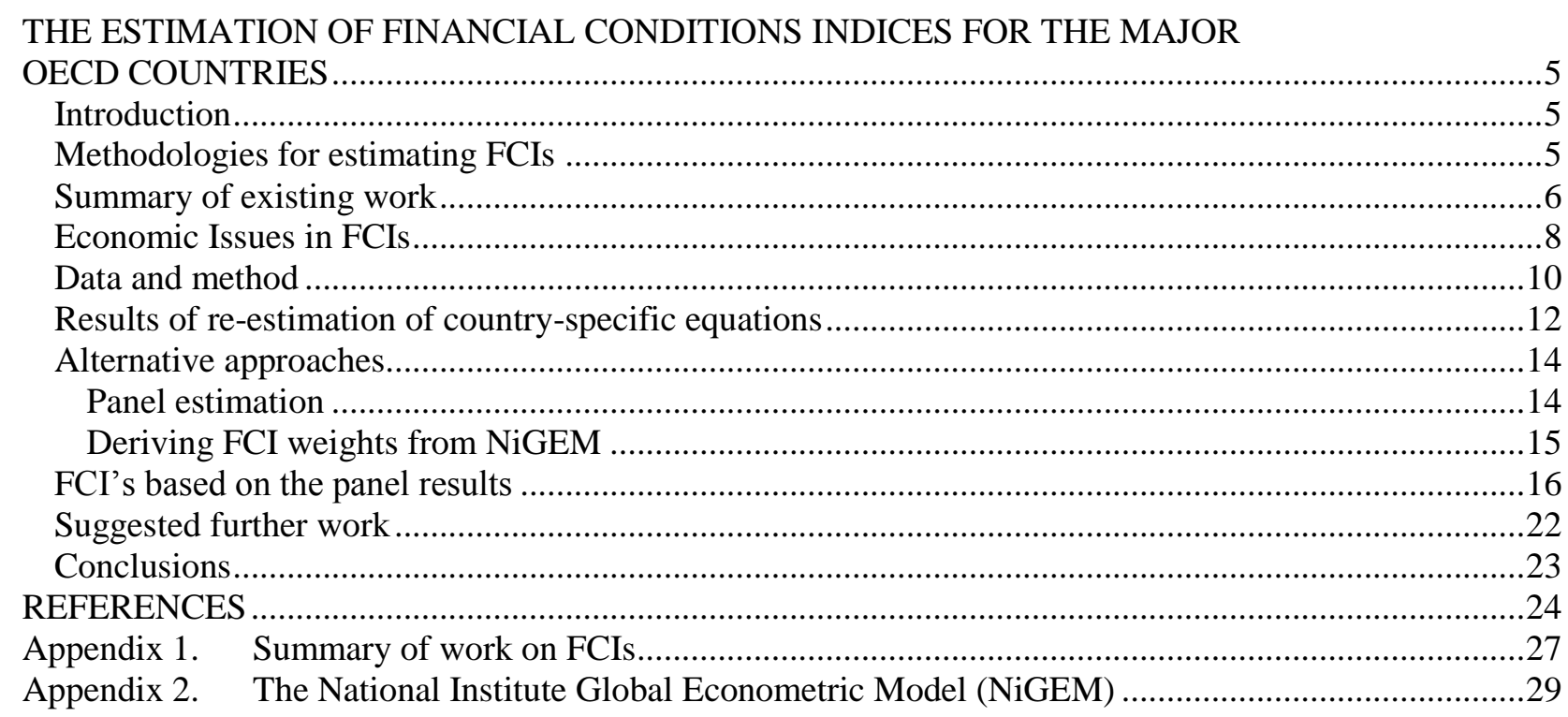

\section{Tables}

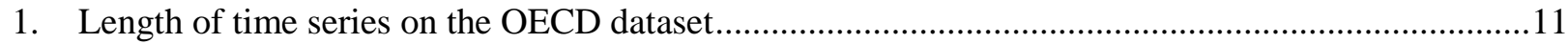

2. Unit roots tests (Augmented Dickey Fuller) on the OECD dataset ..............................................12

3. Results for single equation estimations (significant variables at $90 \%$ or more) ...............................13

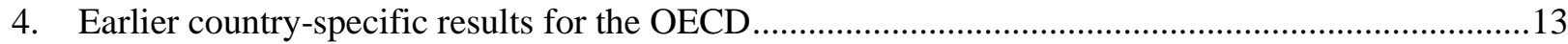

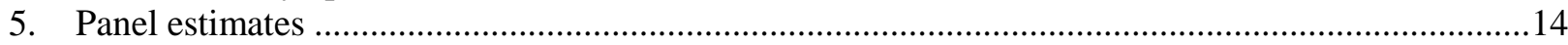

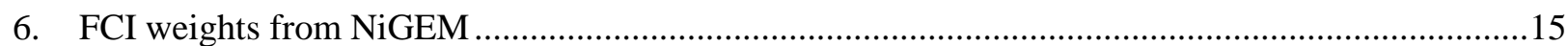

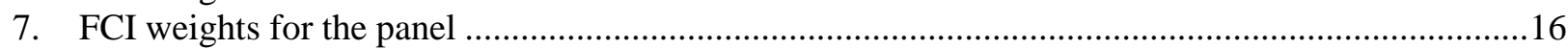

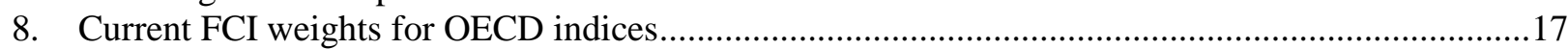

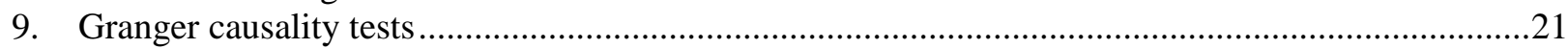

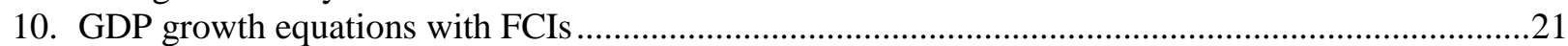

\section{Figures}

1. Financial conditions indices for the major OECD countries .18 
ECO/WKP(2016)59

\title{
THE ESTIMATION OF FINANCIAL CONDITIONS INDICES FOR THE MAJOR OECD COUNTRIES
}

\author{
By E. Philip Davis, Simon Kirby and James Warren ${ }^{1}$
}

\section{Introduction}

The financial crisis of 2007-09 and the fiscal crisis in the euro area have brought to the fore the need for gauging of financial conditions and also accuracy in forecasting GDP growth, especially of turning points and the depth of recessions. Financial conditions indices (FCIs) have been developed for that very purpose, capturing market expectations but also the information captured in quantities and loan/credit conditions surveys to summarise financial conditions and also supplement more traditional macroeconomic forecasting. FCIs have the additional advantage of being updatable in real time, although they are of course vulnerable to the consequences of errors by markets, as was the case in the run-up both to the financial crisis and the euro area difficulties. This paper updates and re-estimates the OECD's FCIs developed in 2008-09 (Guichard and Turner, 2008; Guichard et al., 2009), in the context of a broader review of the state of the art. Accordingly, we begin with an overview of methodologies and issues, illustrated by the existing literature, before going on to provide new estimates of FCIs, including the three largest euro area countries.

\section{Methodologies for estimating FCIs}

There are in general four ways to estimate FCIs. First, reduced form estimates of an equation of the output gap or GDP growth (in effect, the IS curve), with financial variables chosen on the basis of significance, with lags in some cases to allow for the dynamic relation between each variable and growth or the output gap. This approach, in effect, assumes the financial variables are exogenous to each other and to the real economy. As discussed below, this is the main approach adopted by the OECD in 2008 and 2009 and now enshrined in the FCI projections it makes. Gauthier et al. (2004) suggest there can be problems with estimation bias and identification as a result of this assumption.

Second, there are impulse responses from VARs of various kinds, including co-integrated and structural estimates. And relatedly, a third option includes estimation of FCIs via their impact in a large macro model. In general, the VAR and macro model approaches have an advantage in taking into account inter linkages between financial and real variables and between the different financial variables. This may reduce estimation bias and identification problems of the reduced form approach (as well as the simple principal components analysis, discussed below). They can also better capture the dynamic impact of the variable on economic growth and the timing of the overall effect.

1. E. Philip Davis is Fellow at NIESR and Professor of Banking and Finance at Brunel University (emails e_philip_davis@msn.com and p.davis@niesr.ac.uk), Simon Kirby is Head of Macroeconomic Modelling and Forecasting at NIESR, and a member of the Centre for Macroeconomics (email s.kirby@ niesr.ac.uk), James Warren is Research Fellow at NIESR, (email j.warren@niesr.ac.uk). This work was commissioned and funded by the OECD. We thank Sven Blondal, Ane-Kathrine Christensen, Nigel Pain, Lukasz Rawdanowicz, Dave Turner (OECD Economics Department) and Martin Weale (NIESR) and participants at seminars held at NIESR and the OECD for helpful comments, as well as Jérôme Brézillon at the OECD for help with data, and Isabelle Fakih for final document preparation. 
A disadvantage of macro models is that they often do not specify real financial linkages in detail (Gauthier et al., 2004). VARs, it can be argued, capture the dynamic impact of financial conditions on growth, deal with non-exogeneity of regressors and help to identify shocks (Swiston, 2008). On the other hand, the contemporaneous relationship between variables in the system in the presence of shocks to each variable is not defined and has to be assumed, e.g. in the context of the ordering within a Choleski decomposition. An alternative is a generalised impulse response function (Pesaran and Shin, 1998) which takes into full account the historical pattern of correlations observed among different shocks (Gauthier et al., 2004). VARs are typically less theoretically based than macro models, although structural VARs may seek to take theoretical considerations into account.

A fourth approach is factor analyses such as principal component analysis, which allow selection of a large number of variables weighted by their impact on growth, in effect optimising forecasting properties. To avoid issues of simultaneity, in some cases authors have purged variables of the response to developments in demand, prices and monetary policy (Hatzius et al., 2010). The problem is that the reasoning behind including given variables is unclear; it tends to be atheoretical (Mayes and Viren, 2001). A possible approach is to justify categories of variables on a theoretical basis. Investment banks have been major users of such atheoretical FCIs (Hatzius et al., 2010).

Whereas in general the interest is in the direct relation of FCIs to GDP, some FCIs have been developed in terms of an interest rate equivalent, which enables the extent to which monetary policy has offset financial conditions to be measured (Guichard and Turner, 2008; Beaton et al., 2009). As the latter paper shows, this is of particular interest in the context of a zero lower bound for interest rates, and raises the issue of dealing with the impact of quantitative easing in an FCI context.

\section{Summary of existing work}

Appendix 1 provides a summary of work in this area. Mayes and Viren (2001) were an early user of the IS curve reduced form methodology, with a panel approach for EU countries testing how asset prices (housing and stock prices) could help forecast GDP and inflation when added to a basic Monetary Conditions Index (MCI). In general, they found that stock prices were poor indicators in this context, whereas house prices were better indicators, albeit with the disadvantage that periodicity is much longer than for other interest rates and financial prices. A similar result was found by Goodhart and Hofmann (2001).

Typical of VAR work is Swiston (2008) which tests the relation of various measures of lending standards with US GDP and finds that commercial and industrial lending standards are the category with the most significant effect on overall economic activity. He develops from a monetary VAR (with risk-free rates and the exchange rate) with an iterative procedure. A variable is included, if its effect on GDP is correctly signed and significant from a simple VAR, which includes lending standards, short and long-term interest rates, risk spreads on corporate bonds, equity returns and the real effective exchange rate. Two lags were included in a quarterly estimation from 1990-2008. So, for example, volatility measures, quantities of credit and the commercial paper spread are rejected, despite earlier work emphasising their importance. The final model includes real GDP, the GDP deflator, oil prices, equity returns and the real effective exchange rate as well as lending standards, LIBOR, the investment grade bond yield and high-yield bond spread. In the Choleski ordering, lending standards are placed directly after output, inflation and oil prices. ${ }^{2}$

Beaton et al. (2009) use a structural vector error correction model (SVECM) for the United States and contrast it with a macro model based approach. The SVECM starts from a small VAR with real GDP growth, the GDP deflator and the real commercial paper rate. The additional variables which affect GDP

2. LIBOR became increasingly detached from the risk-free rate after the estimation period. 
growth significantly are the business borrowing spread (BAA less Treasuries), loan standards for consumer spending, and financial wealth. Cointegration was found between the business borrowing spread and lending standards for consumer spending, with causality running from the business spread to lending standards. They combine the impulse response function with the model's estimated structural shocks to form the SVECM based FCI (the total contribution to growth in a given quarter from financial conditions). Financial variables account for $32 \%$ of the variance in GDP growth.

The macro model based study by Beaton et al. (2009) uses the Bank of Canada's macro model of the US economy (MUSE), employing all the financial variables in that model; namely the federal funds rate, business borrowing rate, mortgage rate, real effective exchange rate, financial wealth and lending standards for consumer spending, mortgages and business investment. These variables are shocked by one standard deviation. These are then combined with the model's structural shocks to each variable to calculate the contribution to growth in a given quarter from financial conditions. Outcomes from the two types of FCI based on the SVECM and the macro model are similar, although the SVECM based FCI is more volatile, given the forward looking nature of dynamic equations in MUSE. Constraints on policy rates (the zero lower bound) markedly increase the impact of financial conditions on GDP.

Angelopoulou et al. (2013) derive an FCI for the euro area for the limited period from 2003 to 2011, using principal components extracted from a large dataset, and then combined as an FCI. All variables are normalised (demeaned and divided by the standard deviation) but not differenced to stationarity "as there is no estimation". The threshold for the share of variance explained was set at $70 \%$, giving three principal components for the euro area.

The dataset includes in particular the net provision of liquidity and the policy rate to show how monetary policy offset the tightening of financial conditions after the Lehman Brothers' bankruptcy, arguing that including the short-term interest rate alone is insufficient to capture the impact of monetary policy. They also show by individual country FCIs that financial conditions in the euro area were heterogeneous, both before and after the crisis. The variables are grouped as follows: prices, quantities, spreads, volatility, loan surveys and monetary policy variables.

The first principal component includes a variety of the variables, those derived from bank lending survey data playing a particularly important role, along with residential property prices and spreads in the interbank market (3-month compared to the overnight), sovereign spreads and the volatility in the bond market. Bank credit variables (both spreads and quantities) along with security issuance by monetary financial institutions are present in the second principal component. The third component primarily represents the influence of loan-to-deposit spreads and answers to some of the survey questions.

In complementary work, Darracq Paries et al. (2014) estimate principal components for the euro area over 2003-13. The FCI is also incorporated in a VAR, which enables an earlier detection of credit supply shocks. 62 variables are included in the principal components analysis which captures mainly banking sector, bond market and equity market variables as sources of external finance, plus the exchange rate and the raw material prices. The authors do transform variables to stationarity. In common with similar work for the United States (Hatzius et al., 2010), the authors purge financial variables from cyclical and monetary policy influences.

Hollo et al. (2012) compute a composite indicator of systemic stress (CISS) for the euro area that is built up from five sub-indices: bank and non-bank financial intermediaries, money, equity, bond and foreign exchange markets. There are three variables per group, including measures of realised volatility, spreads and correlations. The FCI is computed in two steps. First, the three variables are aggregated by taking their arithmetic mean to form each sub-index. Second, the sub-indices are aggregated on the basis of weights which reflect their time-varying cross-correlation (based on standard portfolio theory) and their 
average relative impact on economic activity. The resulting composite indicator of systemic stress is unit free and rests on an ordinal scale.

The work by Hatzius et al. (2010) for the United States compares simple autoregressions of financial indicators with typical FCIs based on principal components and finds superior forecasting ability for the latter. The authors extend earlier work in a number of ways, not least in using many more variables, including quantities and surveys as well as prices. As mentioned, the 45 series are purged of cyclical and monetary policy influences, and an unbalanced panel approach is used to generate long datasets. As for the euro area, the financial variables are summarised using more than one principal component. The new FCI was a better predictor of GDP growth in the period since the crisis but not earlier. This could suggest variable selection bias or a specification sensitivity to the sample period choice.

In an early study of Canada, Gauthier et al. (2004) try all three approaches using monthly data from 1981 to 2000. They experimented with one set of data detrended using a Hodrick-Prescott (HP) filter and a second set detrended by first-differencing. They then evaluated the different versions of the FCIs based on five criteria: estimated weights on components that are consistent with theory, graphical leading-indicator properties with respect to business cycle turning points, strong dynamic correlation versus the output gap (or monthly growth in real GDP), and in and out-of-sample performance in a simple forecasting exercise for the output gap (or output growth).

Out of eight FCIs based on these three approaches, they found the FCI that derived its weights from the summed coefficients of an IS curve using first-differenced data served the best as a short-term (less than one year) predictor of output growth, whereas the FCI that derived its weights from generalised VAR impulse-response functions using first-differenced data served the best to predict output over the longer term (one to two years). The FCIs also outperformed the MCI in most of the criteria considered.

Guichard and Turner (2008) for the United States also look at different approaches, namely the single equation regression and VAR over 1990-2007. In the output gap equations (equation 5 in Table 2), the preferred specification includes the lagged output gap, the difference of the short-term interest rate, spreads on high-yield corporate bonds, stock market capitalisation and credit standards. The real long-term interest rate, housing wealth and the real exchange rate were excluded as insignificant. Meanwhile the VAR included the same financial variables plus GDP and core inflation, and oil prices as exogenous. As in Gauthier et al. (2004), generalised impulse responses are calculated so responses to shocks are invariant to potentially arbitrary orderings. Real short-term interest rates, high-yield bond spreads, credit standards, real exchange rate and the stock market capitalisation are the financial variables added to GDP growth, core inflation and oil prices in this context. The single equation approach was chosen to form the FCI weights (apart from the equity price and exchange rate that were imposed) although the VAR results were used as a cross check.

Further OECD work (Guichard et al., 2009) extended the approach to other countries (the euro area, Japan and the United Kingdom), albeit often using the US outturns or separate research for calibration, adjusted by features of financial structure, owing to short data periods and to ensure consistency in a crosscountry comparison. There was a particular focus on the analysis of the crisis of 2008-09. Notably the widening of corporate bond spreads was found to account for about half of the deterioration in financial conditions, as did the tightening of credit standards and falling asset prices. Cross comparison with estimated VARs and country-specific equations showed broadly consistent results, although wealth and real long-term interest rates tended to drop out of the VARs.

\section{Economic issues in FCIs}

FCIs developed initially from earlier work on monetary conditions indices (MCIs) used by central banks to summarise their stance (Mayes and Viren, 2001). MCIs usually involved weighting the exchange 
rate and short-term interest rate, and, in some cases, the long-term interest rate. As we have seen above, the additions to MCIs to generate FCIs are generally in three categories: prices and spreads of financial assets, quantities of assets or liabilities, and surveys. There is, however, no clear theoretical basis for which variables should be included and the choice is often empirically guided (Guichard et al., 2009). That said, key background for FCIs is work on the credit channel such as Bernanke and Gertler (1995), highlighting the role of market imperfections in propagating monetary policy; and the growing awareness of the potential importance of asset prices for monetary policy forecasting and setting (Montagnoli and Napolitano, 2004), including via the standard wealth channels to investment and consumption, and the exchange rate's effect on trade. Relevant background is also early work on the predictive power of financial spreads on the economy (Davis and Henry, 1994; Davis and Fagan, 1997) which showed them to be effective predictors of inflation in the United States and the euro area.

In justifying different types of indicator, asset prices may encapsulate market expectations of future growth (e.g. via the dividend discount model for shares), while wealth variables (equity or real estate based) directly affect consumption and investment via wealth effects and Tobin's Q on the one hand and the financial accelerator on the other. Equity prices may be used as a wealth/asset price variable but also the market capitalisation/GDP ratio, household equity wealth or the dividend yield can capture equity market trends (Gauthier et al., 2004). There is a growing interest in house prices as an alternative wealth variable (Goodhart and Hofmann, 2001). Long-term interest rates are not under direct control of the central bank but may strongly influence real activity and accordingly are a relevant component of FCIs separately from MCIs.

Term spreads have an established relation with inflation and growth; see for example Cuaresma et al. (2003), Wheelock and Wohar (2009). Corporate (credit quality) spreads can capture credit rationing effects via the price channel, better than relatively sticky bank lending rates, since they may also indicate nonprice rationing. Meanwhile quantities, notably of lending, can capture additional non-price rationing (the credit channel), as may surveys. Indeed, Swiston (2008) argues that the impact of monetary policy is improperly identified when such indicators of credit availability are not incorporated. But a difficulty outside the United States is short series lengths for such surveys (Guichard et al., 2009).

The nature and use of FCIs may differ between the users. In estimating FCIs, central banks tend to omit the monetary policy instruments (to assess what monetary policy is reacting to) and use FCIs as an indicator usable between forecasting rounds for the whole economy. They have of course to bear in mind that the FCI captures market expectations of the economy but also of the central bank's reaction. And movements in FCIs may reflect shocks to expectations but also portfolio shifts (Mayes and Viren, 2001). Meanwhile international organisations typically use FCIs to summarise the state of the economy, including the evolution of the balance of monetary and fiscal measures in the context of macroeconomic factors. Commercial or investment banks often develop FCIs to help them to assess the central bank's likely behaviour. This is especially the case if monetary authorities target inflation using their own forecasts, and the central bank's instruments themselves affect the FCIs which then affect inflation (Mayes and Viren, 2001). There is an awareness that FCIs matter more and forecast relatively better in times of stress, due to a greater role for market imperfections in such periods (Hansen, 2006).

There are several considerations in using financial variables to forecast GDP growth, as is typical for FCIs (Guichard et al., 2009):

- Causation can run in both directions and hence one may wish to deal with this statistically, as discussed in the sections above.

- Financial variables are highly correlated so there may be double counting, multicollinearity and identification issues. 
- There are structural changes in financial markets that mean that the relationship of a given variable to GDP can vary over time (e.g. due to innovations such as adjustable-rate mortgages and the growth of shadow banks). However, it is always statistically better to have as long an estimation period as possible, covering several cycles.

- The linearity of the relation of variables to GDP growth is not necessarily a correct assumption, not least given the role of bubbles and of pro-cyclical regulation in the impact of financial conditions (Hatzius et al., 2010).

- FCIs are vulnerable to the Lucas critique as policy changes can affect their utility.

- Data availability may limit the ability of the researcher to correctly estimate the relationship of a given indicator to growth, and also periodicity issues may limit the real time use of FCIs (e.g., regarding house prices and surveys which are usually monthly or quarterly).

Further issues affecting all methodologies include model dependence, omitted variables and whether correlation implies causality (Swiston, 2008). Detrending of variables is common (Gauthier et al., 2004) and may be by differencing to stationarity or HP filter, where the latter gives scope for assessing deviation from trend.

\section{Data and method}

The starting point for our work is the dataset used by the OECD for their ongoing use of FCIs in forecasting and economic analysis (Guichard et al., 2009). This involves quarterly data at most from 1970Q1 to 2014Q4 for the euro area, Japan, the United Kingdom and the United States, as well as Germany, France and Italy. The data series are as follows, with their length indicated in Table 1:

- The log difference of real GDP (DLGDP), an approximation of the growth rate of real GDP. ${ }^{3}$

- The differenced real short-term interest rate (DRIRSC), deducting core inflation CPI (domestic definition) from the 3-month interbank rate; expected negative effect.

- The differenced real long-term interest rate (DRIRLC), deducting core inflation using CPI (domestic definition) from 10-year nominal government bond yield; expected negative effect.

- The log difference of real effective exchange rate (DLREER), deflated by relative CPI (domestic definition); expected negative effect.

- Loan survey results $(\mathrm{CCN})$ normalised; expected negative effect.

- Log-difference of real house prices (DLRHP) and share prices (DLRSHP) deflated by CPI (domestic definition); expected positive effect deflated by the CPI. ${ }^{4}$

- Change in bond yield spreads between corporate and government bonds (SPREAD); expected negative effect. The quality of bonds underpinning estimates of the corporate bond yields varies considerable by country.

3. Guichard et al. (2009) used the output gap.

4. Guichard et al. (2009) used financial and non-financial wealth as a per cent of personal disposable income, deviation from the trend. 
ECO/WKP(2016)59

Table 1. The start of time series in the OECD dataset

\begin{tabular}{lccccccc} 
& United States & Euro area & United Kingdom & Japan & Germany & France & Italy \\
\hline RIRSC & 71Q2 & 93Q1 & 97Q2 & 71Q3 & 71Q2 & 71Q2 & 71Q2 \\
RIRLC & 71Q2 & 96Q1 & 97Q2 & 71Q2 & 71Q2 & 71Q2 & 71Q2 \\
REER & 70Q1 & 70Q1 & 70Q1 & 70Q1 & 70Q1 & 70Q1 & 70Q1 \\
CCN & 90Q2 & 99Q1 & 79Q4 & 83Q2 & 03Q1 & 03Q1 & 03Q1 \\
SPREAD & 85Q1 & 98Q1 & 98Q1 & 97Q1 & 01Q2 & 98Q4 & 01Q2 \\
GDP & 70Q2 & 70Q2 & 70Q1 & 70Q2 & 70Q1 & 70Q1 & 70Q1 \\
RHP & 70Q2 & 95Q1 & 70Q1 & 85Q1 & 70Q1 & 70Q1 & 70Q1 \\
RSHP & 70Q2 & 97Q3 & 78Q1 & 85Q1 & 70Q1 & 87Q3 & 97Q4 \\
\hline
\end{tabular}

Note: end period of all series is 2014 Q4.

Source: Authors' compilation.

As discussed above, the output gap has been used in a number of studies. Our preference for the use of real GDP instead of the output gap stems from unreliability of real-time output gaps estimates. For example, Orphanides and van Norden (2002) find for the United States uncertainty over both the magnitude and sign of output gaps in real time. There is a wide divergence in results from different models, while revisions to estimates can be as a large as the output gaps themselves. The role of revisions to the estimates of demand (the observable time series) have little role to play in their conclusions about the unreliability of real time output gap estimates. Massimiliano and Musso (2011) find similar evidence for the euro area, while Murray's (2014) analysis suggests a similar situation for the United Kingdom, again with little role to play for revisions to GDP estimates.

As shown below, the availability of loan officer survey data as a proxy for credit conditions restricts the sample period available for analysis. While the literature exploring the information content of loan surveys suggests predictive power in explaining the variation in a number of variables, including GDP growth, especially in the United States (Driver, 2007), questions have been raised about potential biases. For example, Schreft and Owens (1991) suggest that financial institutions may be biased towards responding that lending standards are tightening.

Alternative real exchange rates based on relative unit labour costs might give different results also, but they would be less useful for timely updating of FCI given longer delays in publishing ULC than CPI. Ideally rather than deducting core inflation, the real long-term interest rate should use inflation expectations, for instance derived from the difference of nominal and index linked bond yields. But not all countries issue the latter, and the relative liquidity of the markets may affect the difference and distort the implicit measure of long-run expected inflation. Alternative proxies include swap rates; household surveys and professional forecasters' expectations. The latter approach is applied by Guichard and Turner (2008). However, only short samples are available for all these measures.

The main constraints on long estimation periods are the credit surveys and the financial spreads. Most other series would permit estimation back to the 1990s or earlier (Table 1).

According to the augmented Dickey-Fuller unit root test, no series is consistently stationary (Table 2). ${ }^{5}$ On balance, our decision was thus to difference all series, with the exception of credit conditions that can clearly not be trended. We note that the spreads and the credit conditions are much more disparate in amplitude as well as having more widely varying time series as shown in Table 1 above. We have thus normalised credit conditions to make them comparable and usable in the panel.

5. Results should be interpreted with caution due to possible structural breaks and generally low power of the test. 
Table 2. Augmented Dickey Fuller unit roots tests

\begin{tabular}{|c|c|c|c|c|c|c|c|}
\hline & United States & Euro area & United Kingdom & Japan & Germany & France & Italy \\
\hline RIRSC level & -2.1 & -2.7 & -1.6 & -2.1 & -3.6 & -3.2 & -2.6 \\
\hline Difference & -11.4 & -5.2 & -4.4 & -13.2 & -9.6 & -9.7 & -10.8 \\
\hline RIRLC level & -2.8 & -1.9 & -1.6 & -2.4 & -2.2 & -2.7 & -2.0 \\
\hline Difference & -8.2 & -5.6 & -5.9 & -7.6 & -10.8 & -9.1 & -8.7 \\
\hline Log RER level & -2.9 & -2.7 & -2.8 & -2.3 & -3.0 & -3.2 & -2.8 \\
\hline Difference & -9.6 & -10.3 & -10.9 & -6.3 & -10.8 & -10.5 & -9.6 \\
\hline CCN level & -2.9 & -1.6 & -1.7 & -2.3 & -4.2 & -4.5 & -2.6 \\
\hline Difference & -9.3 & -6.9 & -18.7 & -7.6 & -9.0 & -7.4 & -7.3 \\
\hline SPREAD level & -4.3 & -3.2 & -3.9 & -2.5 & -2.7 & -7.8 & -3.1 \\
\hline Difference & -8.9 & -5.9 & -6.6 & -7.7 & -5.8 & -9.2 & -10.3 \\
\hline Log GDP level & 1.0 & -1.0 & 0.4 & -2.4 & -0.6 & -1.1 & -2.3 \\
\hline Difference & -9.6 & -7.3 & -7.1 & -10.8 & -11.0 & -5.3 & -7.3 \\
\hline Log RHP level & -1.7 & -2.3 & 1.1 & -0.8 & -1.9 & -1.3 & -2.2 \\
\hline Difference & -3.5 & -1.8 & -4.8 & -3.1 & -5.1 & -3.6 & -3.8 \\
\hline Log RSHP level & -0.5 & -1.9 & -1.6 & -1.9 & -0.8 & -2.5 & -1.3 \\
\hline Difference & -9.1 & -5.3 & -10.1 & -7.5 & -9.2 & -6.7 & -5.8 \\
\hline \multicolumn{8}{|l|}{ Memorandum } \\
\hline GAP level & -1.7 & -2.3 & -2.7 & -3.1 & & & \\
\hline Difference & -6.2 & -4.4 & -4.6 & -7.2 & & & \\
\hline WEALTH level & -2.2 & -0.9 & -0.9 & -1.2 & & & \\
\hline Difference & -4.4 & -6.8 & -7.8 & -12.3 & & & \\
\hline
\end{tabular}

Note: Critical value for a unit root is roughly -2.9. RIRSC is real short rate deflated by core inflation using CPI (domestic definition). RIRLC is real long rate deflated by core inflation using CPI (domestic definition). REER is the real effective exchange rate using relative CPI (domestic definition). CCN is the credit conditions survey, normalised. SPREAD is the corporate-government bond spread. GDP is gross domestic product. RHP is real house prices deflated by consumer prices (domestic definition). RSHP is real share prices deflated by consumer prices (domestic definition). GAP is the output gap, derived from a production function approach.

Source: Authors' calculations.

\section{Results of re-estimation of country-specific equations}

We initially estimated the FCIs for the seven areas using the single equation country-specific approach based on the OECD data for as long a period as possible up to 2014Q4. Compared with Guichard and Turner (2008) and Guichard et al. (2009), the main difference is that we have the difference of real housing and stock prices, rather than the gap from wealth trend as the wealth variables as well as the log difference of GDP rather than the output gap as the dependent variable. We also expanded the sample of countries to include Germany, France and Italy. The interest rates, spreads and real exchange rate are entered as differences. We tested down from 4 lags to those remaining significant. We note that such reduced form estimates are likely to suffer from omitted variables problems.

The table below summarises the main results. There are a number of wrong signs as compared with expectations. These include house prices and short-term interest rates for Japan; and house prices, longterm rates and the exchange rate for Germany. Furthermore, there are a large number of zero coefficients at conventional significance levels which reduces the usefulness of these estimates for constructing FCIs. 
ECO/WKP(2016)59

Table 3. Results for single equation estimations

Significant variables at $90 \%$ or more

\begin{tabular}{|c|c|c|c|c|c|c|c|}
\hline & United States & Euro area & United Kingdom & Japan & Germany & France & Italy \\
\hline Constant & 0.004 & 0.002 & 0.001 & & -0.006 & 0.001 & \\
\hline $\operatorname{DLGDP}(-1)$ & & 0.286 & 0.445 & & & & 0.360 \\
\hline $\operatorname{DLGDP}(-2)$ & 0.189 & & & & -0.287 & & \\
\hline $\operatorname{DLGDP}(-3)$ & & & & -0.311 & & & \\
\hline $\mathrm{CC}(-1)$ & -0.002 & & & & -0.005 & -0.002 & \\
\hline $\operatorname{CC}(-3)$ & & & & & -0.006 & & \\
\hline $\operatorname{DLRHP}(-1)$ & 0.145 & & 0.121 & & & 0.174 & 0.164 \\
\hline $\operatorname{DLRHP}(-2)$ & & 0.270 & & -0.199 & & & \\
\hline $\operatorname{DLRSHP}(-1)$ & 0.021 & 0.035 & 0.015 & 0.037 & & 0.020 & 0.027 \\
\hline DLRSHP(-2) & & & 0.015 & & -0.031 & -0.019 & \\
\hline DLRSHP(-3) & & & & & & & 0.016 \\
\hline DRIRSC(-1) & -0.004 & & -0.003 & 0.002 & & & \\
\hline DRIRSC(-2) & & & & & -0.007 & & -0.003 \\
\hline DRIRLC(-1) & & & & & 0.009 & -0.003 & \\
\hline DLREER(-1) & & & & -0.059 & 0.157 & & \\
\hline DLREER(-3) & & & & -0.062 & & & \\
\hline DSPREAD $(-1)$ & & & & & -0.008 & -0.004 & \\
\hline DSPREAD (-2) & & & & -0.011 & & & \\
\hline
\end{tabular}

Note: DLGDP is the log first difference of gross domestic product. CCN is the credit conditions, normalised. DLRHP is the log first difference of real house prices deflated by CPI (domestic definition). DLRSHP is the log difference of real share prices deflated by $\mathrm{CPI}$ (domestic definition). DRIRSC is the first difference of real short rates deflated by core CPI (domestic definition). DRIRLC is the first difference of real long rates deflated by core CPI (domestic definition). DLREER is the log first difference of the real effective exchange rate (based on relative CPI inflation on domestic definitions). DSPREAD is the change in the spread between corporate and government bonds.

Source: Authors' calculations.

Table 4. Earlier country-specific results for the OECD

Dependent variable: Output gap

\begin{tabular}{lcccc} 
& United States & Euro area & United Kingdom & Japan \\
\hline WEALTH & + & + & + & - \\
SPREAD & - & - & - & - \\
CC & - & - & - & - \\
REER & ins & - & - & - \\
RSR & - & - & - & - \\
RLR & - & - & - & - \\
\hline
\end{tabular}

Note: Effects shown are in levels. WEALTH is real household wealth, SPREAD is the spread between corporate and government bonds, CC is the credit conditions, REER is the real effective exchange rate, RSR is the real short rate, and RLR is the real long rate. For the United States, the long rate effect was calibrated; for the euro area, Japan and the United Kingdom, all variables were calibrated based on the US results.

Source: Table 2 in Guichard et al. (2009), "Quantifying the Effect of Financial Conditions in the Euro Area, Japan, United Kingdom and United States", OECD Economics Department Working Papers, No. 677, OECD Publishing, Paris.

A key difference from earlier results from Guichard et al. (2009), shown in Table 4, are that long-term interest rates were estimated or calibrated as having a negative effect on the output gap while the real exchange rate was taken as negative. The differences may result from the period now used in the dataset that includes the financial crisis and the period of sustained low interest rates which followed. Also the earlier results for all countries included calibrated as well as estimated coefficients thus "filling the gaps" where at present we have zero coefficients.

Commenting on our new results in general, it is notable that they differ markedly from earlier estimates. Even with small changes of sample, we can get major changes in results; for example, the 
significance of variables in the case of France. We later report on a partial calibration using panel coefficients to complete gaps or replace wrong signs.

In our preliminary work we also estimated VARs but the results are not sufficiently helpful to be included here.

\section{Alternative approaches}

\section{Panel estimation}

As a first alternative approach to the basic analysis, we undertook unbalanced panel estimates for the set of countries and/or the euro area excluding Germany, France and Italy. Referring to the dates shown in Section 5, this obviously takes more of a time series from the United States than others since more data are available. As in the country-specific results, we are differencing all variables except the credit restrictions (CC). The CC variable is normalised to be similar in mean across countries. The interest rates are defined relative to core inflation as above. We did one set with just the first lag and a second set testing down from four lags to the significant variables and/or those with correct signs, however, the results are similar so we present only the best results for 6 countries (excluding the euro area), with all signs as expected (Table 5).

Looking at the results for the full period, only some variables are significant; the constant, lagged GDP growth, share prices, house prices and the real exchange rate (at 90\%). All variables have the right sign. We decided that this panel offers a useful estimate that could be used in principle for each country. We also show results in Table 5 for the period before and after the 2007 financial crisis, making a division at 2007Q3. This also shows broadly the new data that have been added since the earlier OECD estimates (albeit we also include the new countries Germany, France and Italy). There is shown to be a reasonable degree of parameter stability. The main differences are that the lag of GDP growth is lower while wealth effects are higher in the post crisis period. The post crisis period is quite in line with the full sample, however. The other variables are consistent across all three panels albeit often not significant.

Results shown in the last columns are also similar for the set of four countries that the OECD previously covered, again with consistent results.

Table 5. Panel estimates

\begin{tabular}{|c|c|c|c|c|c|c|c|c|}
\hline & \multicolumn{2}{|c|}{ 1980Q1-2014Q4 } & \multicolumn{2}{|c|}{ 2007Q3-2014Q4 } & \multicolumn{2}{|c|}{ 1980Q1-2007Q2 } & \multicolumn{2}{|c|}{$\begin{array}{c}\text { USA, GBR, EA, JPN } \\
\text { 1980Q1-2014Q4 }\end{array}$} \\
\hline & Coeff & $t$ value & Coeff & $t$ value & Coeff & t value & Coeff & $t$ value \\
\hline Constant & 0.002 & 5.43 & 0.001 & 1.93 & 0.004 & 6.82 & 0.003 & 6.22 \\
\hline $\operatorname{DLGDP}(-1)$ & 0.230 & 4.42 & 0.150 & 1.90 & 0.239 & 3.40 & 0.194 & 3.34 \\
\hline $\operatorname{CCN}(-1)$ & -0.001 & -1.53 & -0.001 & -1.27 & -0.001 & -1.40 & 0.000 & -0.85 \\
\hline $\operatorname{DLRHP}(-1)$ & 0.122 & 5.37 & 0.148 & 3.48 & 0.062 & 2.65 & 0.146 & 5.77 \\
\hline $\operatorname{DLRSHP}(-1)$ & 0.035 & 7.03 & 0.043 & 5.55 & 0.021 & 3.49 & 0.036 & 6.29 \\
\hline DSPREAD(-2) & 0.000 & -1.03 & 0.000 & -0.47 & -0.001 & -1.59 & 0.000 & -0.98 \\
\hline DRIRLC(-3) & -0.001 & -1.32 & 0.000 & -0.18 & -0.002 & -1.67 & -0.001 & -1.23 \\
\hline DRIRSC(-1) & -0.001 & -1.02 & -0.002 & -1.17 & -0.001 & -0.51 & 0.000 & -0.42 \\
\hline DLREER(-3) & -0.024 & -1.85 & -0.033 & -1.55 & -0.013 & -0.89 & -0.023 & -1.88 \\
\hline Adjusted R-squared & 0.366 & & 0.367 & & 0.208 & & 0.355 & \\
\hline S.E. of regression & 0.007 & & 0.008 & & 0.005 & & 0.006 & \\
\hline Observations & 373 & & 180 & & 193 & & 295 & \\
\hline
\end{tabular}

Note: DLGDP is the log first difference of gross domestic product. CCN is the credit conditions normalised. DLRHP is the log first difference of real house prices deflated by CPI (domestic definition). DLRSHP is the log difference of real share prices deflated by $\mathrm{CPI}$ (domestic definition). DRIRSC is the first difference of real short rates deflated by core CPI (domestic definition). DRIRLC is the first difference of real long rates deflated by CPI inflation (domestic definition). DLREER is the log first difference of the real effective exchange rate (based on relative CPI inflation on domestic definitions). DSPREAD is the change in the spread between corporate and government bonds.

Source: Authors' calculations. 


\section{Deriving FCI weights from NiGEM}

Alongside the weights derived from the country-specific equations and the panel estimations we provide weights derived from the National Institute Global Econometric Model (NiGEM), see Appendix 2. With the exception of credit conditions surveys, NiGEM contains analogous variables to those utilised in the regression analysis presented above. Furthermore, the imposed theoretical structure will ensure that the weights derived have the correct sign and will not be affected by data limitations. While all country models in NiGEM have the same structure, the parameterisations are country-specific which ensures that the weights for each shock will vary across countries, in contrast with the panel estimation.

The weights are constructed broadly in the same way as the regression examples (Table 6). We apply a shock so that the variable in question increases by one percentage point, we then take the average effect on GDP over the 4 to 6-quarter horizon. For each scenario, we run the shocks with forward-looking expectations and the default monetary policy rule where the central bank adjusts the interest rate to close the gap between the nominal interest rate and inflation from their respective targets. In the euro area, the central bank targets euro area aggregates.

An important point to note is that the cause behind shocks is important within a structural model such as NiGEM. For example, a risk premium shock and a technology shock which causes a 1-percentage point increase in the exchange rate have quantitatively different effects on an economy, as illustrated using NiGEM by Kirby and Meaning (2014). Moreover, as the transmission of the shocks occur through explicit mechanisms with rational expectations, the choice of implementing a temporary or permanent shock will also have important effects, not just on the overall size of the shock but the profile of GDP throughout our scenario period. The exercise here should be viewed as an illustrative example of how weights could be derived through NiGEM; a more accurate example would seek to calibrate the shocks in order to reflect scenarios which affect specific financial conditions both in size and duration.

To ensure clarity of the process used to derive the shocks we briefly describe the shocks applied and where necessary the transmission mechanism by which they affect GDP. The spread variable used in the regression weightings of the FCI is directly comparable to the investment premium in NiGEM. While in order to get an increase in the real long rate we apply shock to the term premia. In both cases we apply a 1-percentage point shock. Both shocks are transmitted through the user cost of capital which through the difference between the current level of the capital stock and optimal levels of capital stock reduces investment. The pass-through to firms' unit total costs will affect inflation; due to the relative power of both of these shocks, we apply both of these as temporary shocks with a duration of two years.

For share prices we reduce the equity premium by 1 percentage point. This will feed through into household net wealth and consumption. Once again we introduce this as a temporary 2-year shock. While, for house prices we impose directly a positive $1 \%$ shock.

Table 6. FCl weights from NiGEM

\begin{tabular}{lccccccc} 
& United States & Euro area & United Kingdom & Japan & Germany & France & Italy \\
\hline CCN & $\mathrm{N} / \mathrm{A}$ & $\mathrm{N} / \mathrm{A}$ & $\mathrm{N} / \mathrm{A}$ & $\mathrm{N} / \mathrm{A}$ & $\mathrm{N} / \mathrm{A}$ & $\mathrm{N} / \mathrm{A}$ & $\mathrm{N} / \mathrm{A}$ \\
RIRS & -0.321 & -0.348 & -0.337 & -0.477 & -0.344 & -0.305 & -0.223 \\
RIRL & -0.942 & -0.791 & -0.400 & -0.854 & -0.562 & -0.667 & -0.612 \\
DLRHP & 0.309 & 0.135 & 0.236 & 0.238 & 0.086 & 0.189 & 0.083 \\
DLRSHP & 0.055 & 0.014 & 0.035 & 0.003 & 0.024 & 0.002 & 0.009 \\
DLREER & 0.276 & 0.035 & -0.067 & 0.077 & 0.021 & 0.063 & 0.045 \\
SPREAD & -0.519 & -0.604 & -0.123 & -0.560 & -0.438 & -0.495 & -0.565 \\
\hline
\end{tabular}

Note: The real rates and spread effects are in levels. NiGEM weights are larger than those in the panel due to scaling.

Source: Authors' calculations. 
The real short-term interest rate is applied as a simple shock to the central bank's intervention rate as described above with the usual transmission through to the economy. Exchange rates in NiGEM are modelled with a uncovered interest parity (UIP) condition adjusted with a risk premium, so we shock the risk premium and calibrate it such that the real effective exchange rate appreciates by approximately 1 percentage point. It is useful to note that all exchange rates in NiGEM are bilateral to the United States, so in order to achieve an appreciation of the US currency, this requires all other countries in NiGEM to depreciate equally. For both the short-term interest rate and the exchange rate shocks, the euro area aggregate variables are used.

For three of the premium shocks (investment, equity and term premia), as well as house prices there is not a euro area aggregate variable which can be shocked. For the euro area we apply the shocks described above to all member states. This, however, is likely to be less than desirable, as a result of the interlinkages resulting from trade and financial flows within NiGEM. For example, a contraction occurring simultaneously across the EMU, will depress demand in all countries in the aggregate as a result this will spillover and reduce exports and therefore output in a much greater manner than the effects of a single country contracting. Furthermore, the relative size and trading importance of an economy is also important. For instance, a contraction within France will have larger spillovers throughout the rest of Europe than would Ireland. Ideally, the weightings for each of these variables would be calibrated as single country, level effects and then fed into the euro area as single elements.

From the weights, the effect from house prices through to GDP is relatively small in NiGEM when compared with the panel and country-specific estimations. As house prices are within the FCI partly as a proxy for households' access to collateralised credit, an alternative lever such as a direct increase in the consumer credit rate for households or the number of consumer constrained households could be used. However, substitution with the latter variables could well exclude the direct wealth effects that house prices should also capture.

The exchange rate has positive effects except for the United Kingdom. As noted above, it is the nature of the shock to the exchange rate itself that matters for the impact of the movement in the real economy (Kirby and Meaning, 2014).

\section{FCI's based on the panel results}

We went on to derive FCIs from the panel results described above, which is the impact of each variable after 6 quarters. We have chosen to highlight the panel as the key set of results since it has correct signs for all variables. As in the earlier work by the OECD, this is a question of deriving weights for each variable and then using them to weight each variable in the FCI, the result is a set of charts which identify both the overall FCI and the contribution of each variable (Table 7).

Table 7. FCl weights for the panel

\begin{tabular}{lc}
\multicolumn{1}{c}{ Variable } & Weights \\
\hline Credit conditions & -0.005 \\
Log difference of real house prices & 0.904 \\
Log difference of real share prices & 0.257 \\
Difference of corporate - government spread & -0.002 \\
Difference of real long rates & -0.006 \\
Difference of real short rates & -0.007 \\
Log difference of real effective exchange rate & -0.117 \\
\hline
\end{tabular}

Source: Authors' calculations. 
Table 8. Current FCl weights for OECD indices

\begin{tabular}{lcccc} 
& United States & Euro area & United Kingdom & Japan \\
\hline Credit conditions & -0.026 & -0.033 & -0.309 & 0.067 \\
High-yield corporate bond spread & -0.280 & -0.162 & -0.909 & -1.211 \\
Real short-term interest rates & -0.180 & -0.116 & -0.180 & -0.116 \\
Real long-term interest rates & -0.590 & -0.380 & -0.590 & -0.380 \\
Real exchange rate & -0.089 & -0.118 & -0.177 & -0.089 \\
Household financial \& housing wealth & 0.018 & 0.016 & 0.016 & 0.015 \\
\hline
\end{tabular}

Note: technically the euro area result is outside the estimation as the panel chosen is for 6 countries (albeit including the three major countries in the euro area).

Source: Guichard et al. (2009), "Quantifying the Effect of Financial Conditions in the Euro Area, Japan, United Kingdom and United States", OECD Economics Department Working Papers, No. 677, OECD Publishing, Paris.

We also show in Table 8 the current OECD weights, which as noted above are mainly based on calibrated variables except for the United States.

Figure 1 presents the FCIs as derived from the results of the panel estimation. In order to interpret the indexes it is worth noting that a downward movement in the FCI represents a tightening of financial conditions and vice versa. Given that the weights are derived from panel estimations the weights across countries are the same. As a result, a number of generalisations can be drawn across the FCIs. First, the largest contributors to the final index are real share and house prices. This result may be plausible for the United Kingdom and the United States, however, for the European economies and Japan, it is less appealing. Credit conditions are the next largest contributor, while the interest rate and real effective exchange rate series' contributions are smaller. Given this, it is unsurprising that the period of the financial crisis which coincided with sharp falls in both house and share prices is captured across all countries. The sovereign debt crisis period in Europe is also captured. However, although Germany is less affected than Italy or France as would be expected, this occurs mainly as a result of moderate growth in house prices rather than a divergence in long-term interest rates between these countries as investors shifted to perceived safer assets. It could be interpreted that the movement of the FCI represents a symptom of financial conditions within these countries rather than a driver of their underlying state. 
Figure 1. Financial conditions indices for the major OECD countries

\section{A. United States}

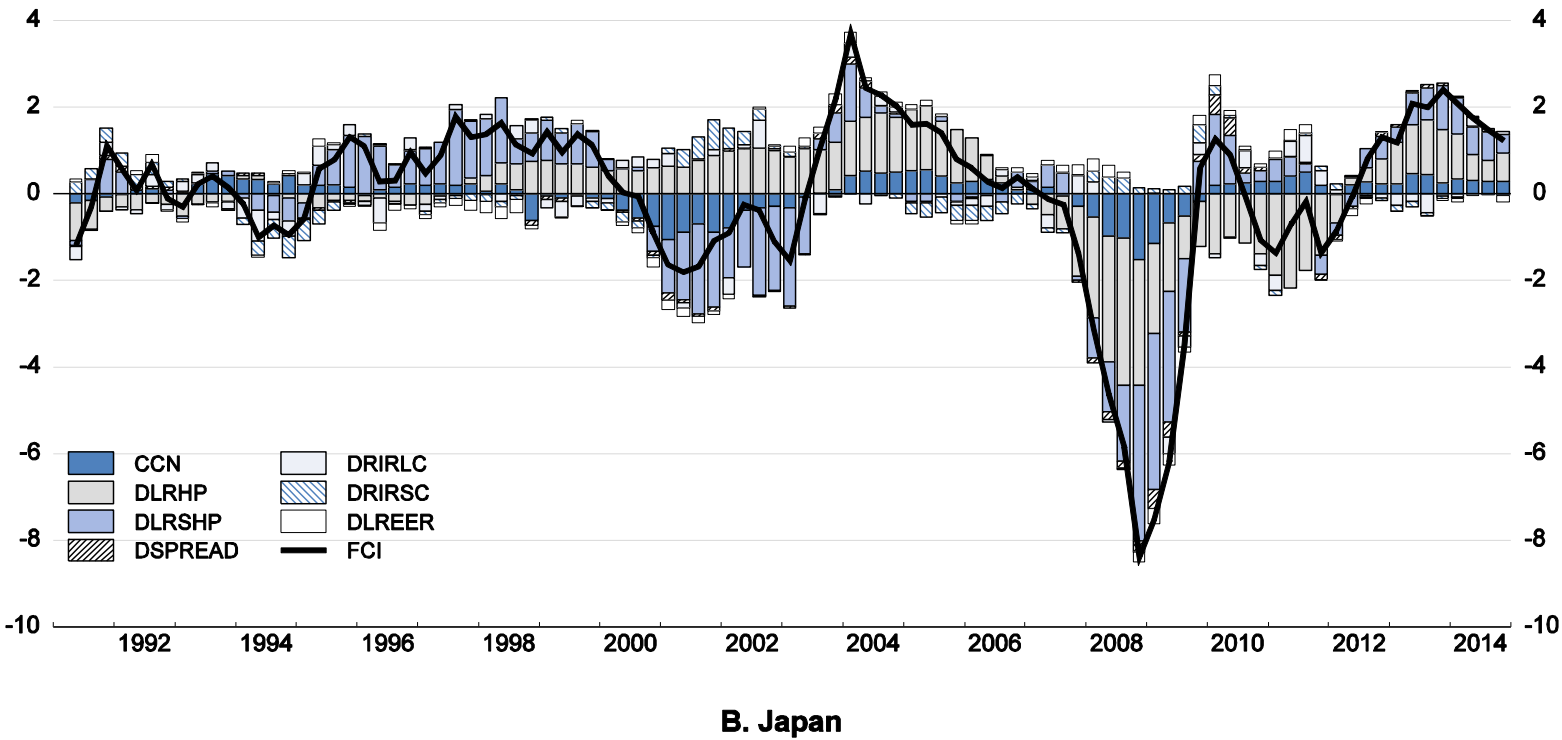

6

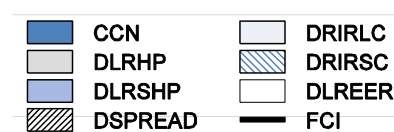

DSPREAD

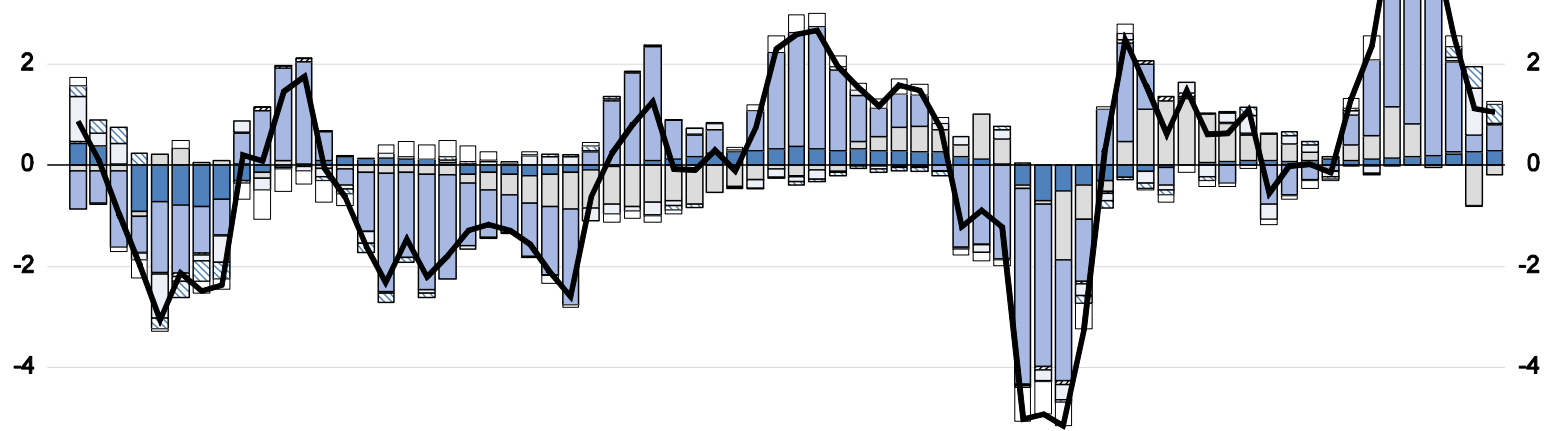

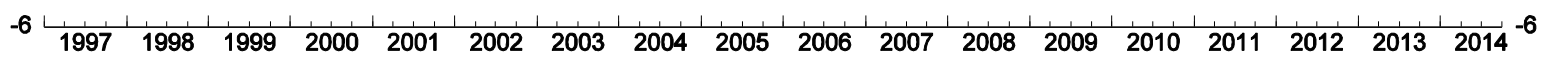

Note: The chart decomposes the financial conditions index $(\mathrm{FCl})$ into its weighted components: $\mathrm{CCN}$ is normalised credit conditions, DLRHP is the log first difference of real house prices deflated by private consumption deflator (national account definition), DLRSHP is the log difference of real share prices deflated by CPI (harmonised definition), DRIRSC is the first difference of real short rates deflated by core CPI (harmonised definition), DRIRLC is the first difference of real long rates deflated by core CPI (harmonised definition), DLREER is the log first difference of the real effective exchange rate (based on relative CPI inflation on harmonised definitions), and DSPREAD is the change in the spread between corporate and government bonds.

Source: Authors' calculations. 
Figure 1. Financial conditions indices for the major OECD countries (cont.)

\section{Euro area}

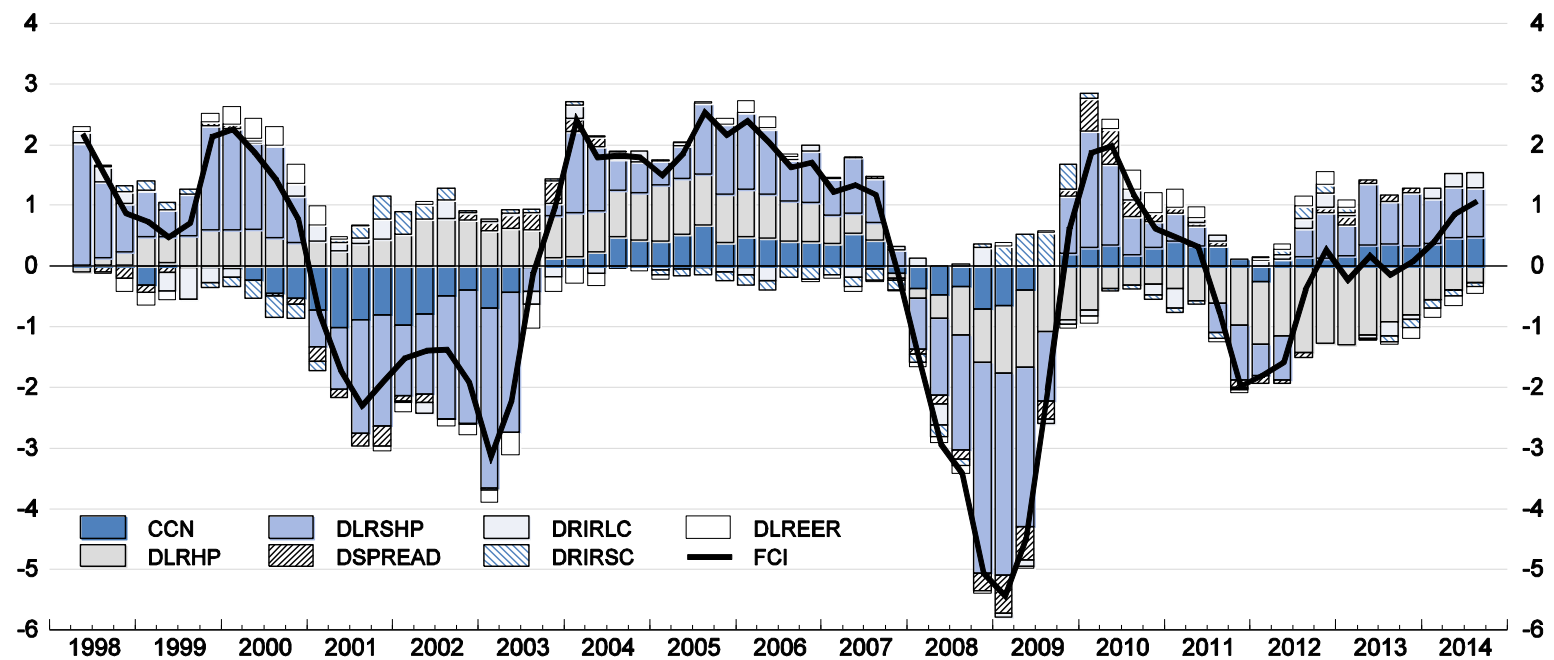

\section{United Kingdom}

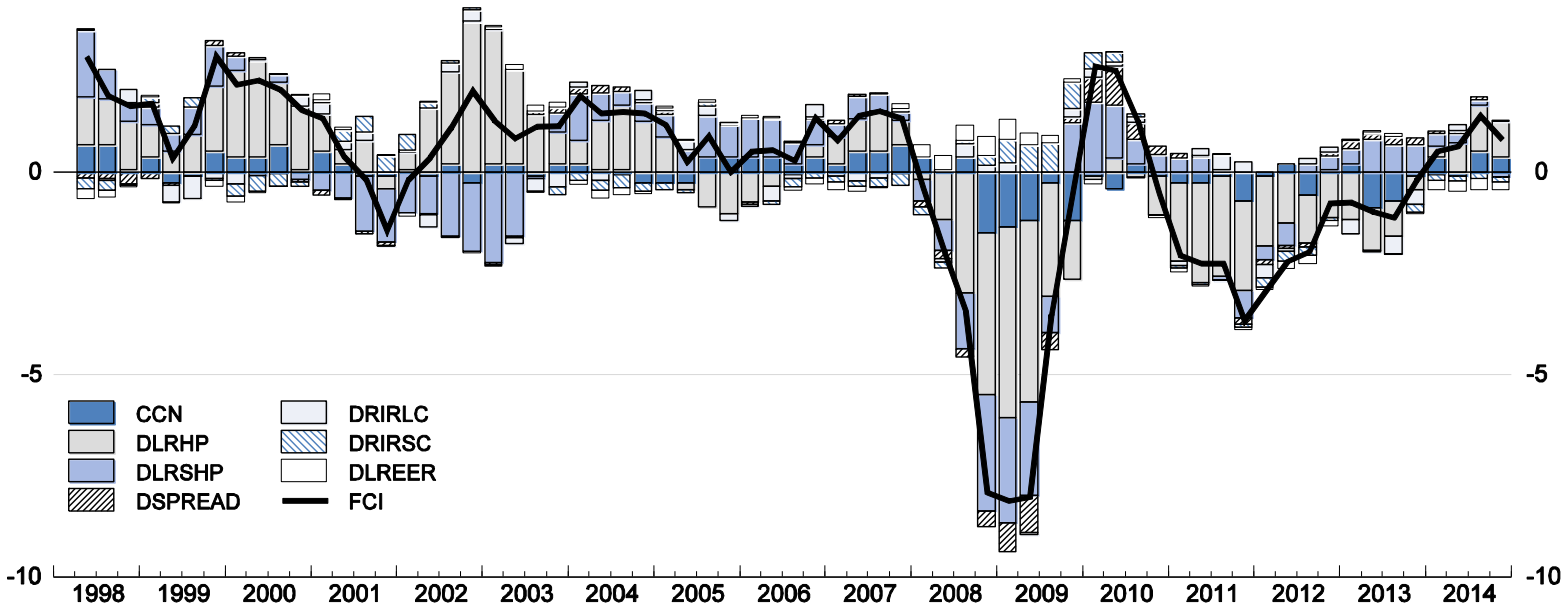

Note: The chart decomposes the financial conditions index ( $\mathrm{FCl}$ ) into its weighted components: $\mathrm{CCN}$ is normalised credit conditions, DLRHP is the log first difference of real house prices deflated by private consumption deflator (national account definition), DLRSHP is the log difference of real share prices deflated by CPI (domestic definition), DRIRSC is the first difference of real short rates deflated by core CPI (domestic definition), DRIRLC is the first difference of real long rates deflated by core CPI (domestic definition), DLREER is the log first difference of the real effective exchange rate (based on relative CPI inflation on domestic definitions), and DSPREAD is the change in the spread between corporate and government bonds.

Source: Authors' calculations. 
Figure 1. Financial conditions indices for the major OECD countries (cont.)

\section{E. Germany}

4
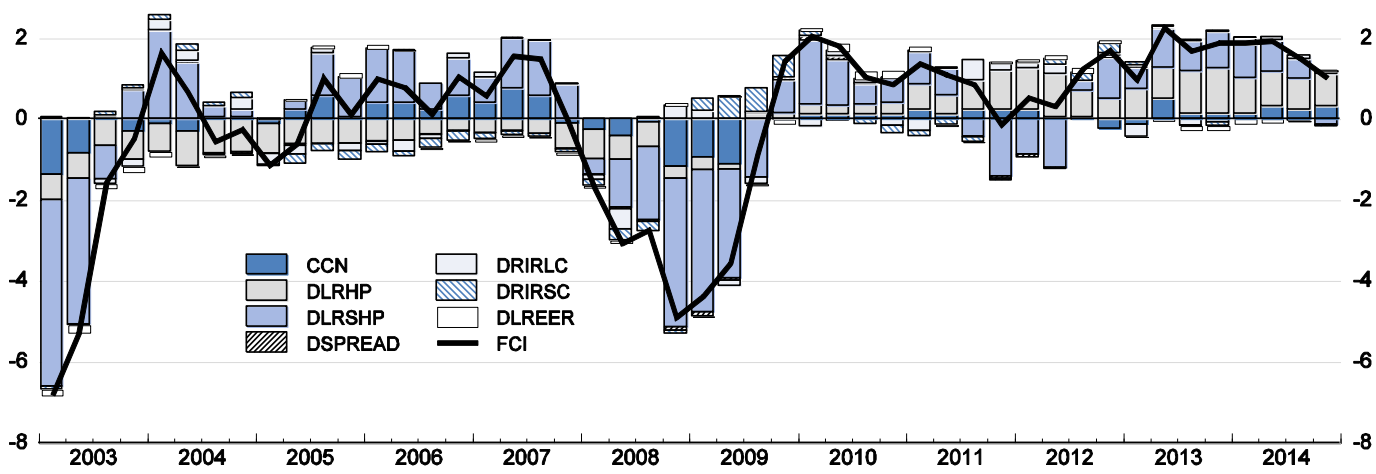

F. France

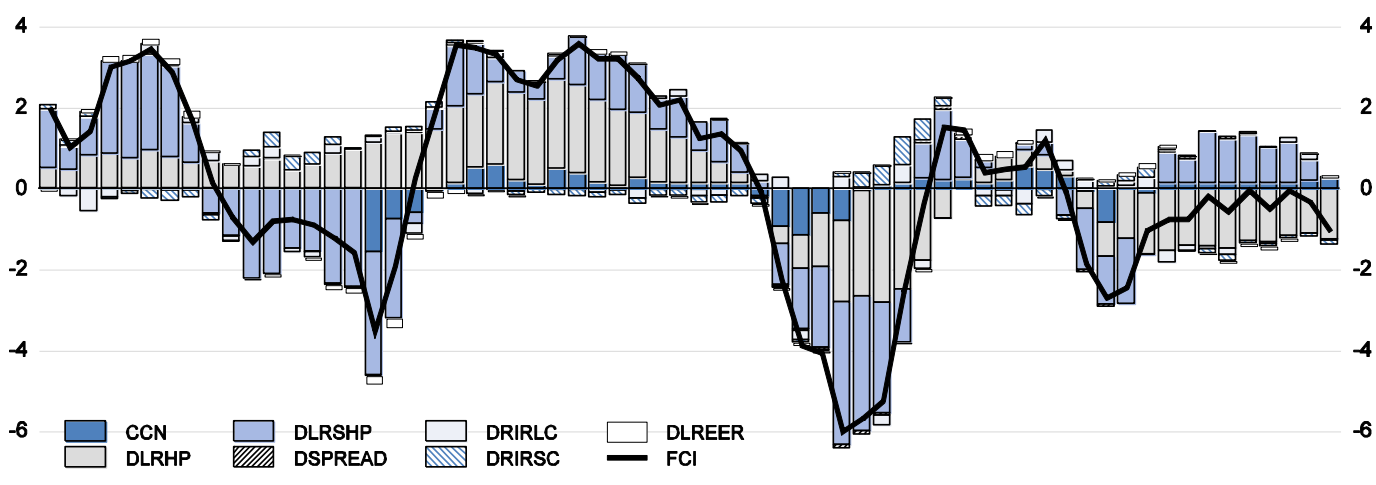

$\begin{array}{llllllllllllllllll}-8 & 1999 & 2000 & 2001 & 2002 & 2003 & 2004 & 2005 & 2006 & 2007 & 2008 & 2009 & 2010 & 2011 & 2012 & 2013 & 2014 & -8\end{array}$

\section{G. Italy}

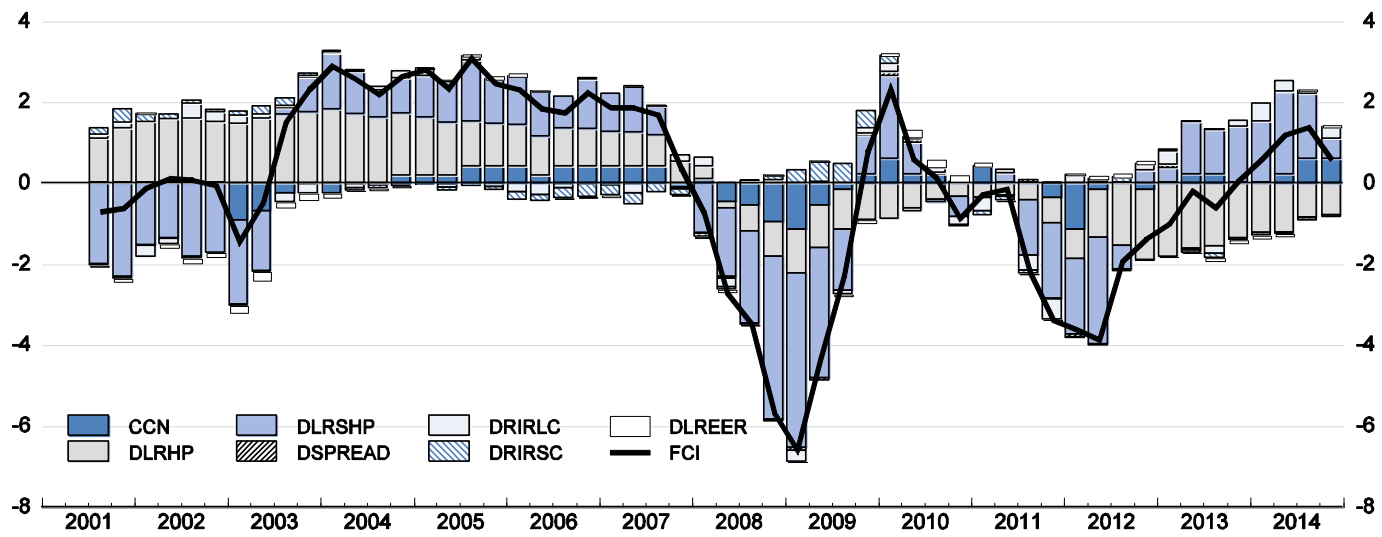

Note: The chart decomposes the financial conditions index (FCl) into its weighted components: CCN is normalised credit conditions DLRHP is the log first difference of real house prices deflated by private consumption deflator (national account definition), DLRSHP is the log difference of real share prices deflated by CPI (domestic definition), DRIRSC is the first difference of real short rates deflated by core CPI (domestic definition), DRIRLC is the first difference of real long rates deflated by core CPI (domestic definition), DLREER is the log first difference of the real effective exchange rate (based on relative CPI inflation on domestic definitions), and DSPREAD is the change in the spread between corporate and government bonds.

Source: Authors' calculations. 
Table 9 below tests the FCIs in terms of their panel Granger causality with GDP. For around half of the countries the Granger Causality tests suggests a one way causal link with the FCI being helpful to predict GDP rather than the other way around. The exceptions to this are Germany, the United Kingdom and Italy. For Germany, the test suggests that the causal direction is strongest in the direction of the FCI causing GDP, however, this would be marginally rejected at the 5\% level. For the United Kingdom, similarly to Germany, the FCI causing GDP would be marginally rejected at the 5\% level, but the test suggests strong causation in the opposite direction. This result may be unsurprising given the primacy of house prices in the index and that, while these co-moved during the Great Recession the recovery in GDP began before the trough in house prices. For Italy, the FCI neither Granger causes or is Granger caused by GDP.

Table 10 shows the role of FCIs derived from the panel estimations in explaining GDP growth. This is more demanding in some ways than Granger causality as it includes other conditioning variables: oil prices, external demand and fiscal balance. We checked for stationarity using the ADF test and transformed where appropriate. Consequently, all variables are in differences, except the FCI. The FCI is significant as a determinant of GDP in all countries. This is corroborated by the $\mathrm{P}$ value of the $\mathrm{F}$ tests for FCI omission. Given these estimated equations, a temporary 1-unit increase in FCI raises GDP level after 6 quarters by between $0.09 \%$ and $0.33 \%$, except for Japan where the positive GDP impact is only up to the fifth quarter.

Table 9. Granger causality tests

\begin{tabular}{lcccc} 
& $\begin{array}{c}\text { FCl do not Granger cause GDP } \\
\text { Fstat }\end{array}$ & $\begin{array}{c}\text { Prob } \\
\text { GDP do not Granger cause } \mathbf{~ F C l} \\
\text { Prob }\end{array}$ \\
\hline United States & 10.1 & 0.000 & 1.5 & 0.225 \\
Euro area & 5.9 & 0.005 & 1.5 & 0.230 \\
United Kingdom & 3.0 & 0.060 & 9.9 & 0.000 \\
France & 9.0 & 0.000 & 0.7 & 0.491 \\
Italy & 0.4 & 0.664 & 2.7 & 0.078 \\
Japan & 6.2 & 0.004 & 3.7 & 0.030 \\
Germany & 3.2 & 0.053 & 0.5 & 0.600 \\
\hline
\end{tabular}

Source: Authors' calculations.

Table 10. GDP growth equations with FCls

\begin{tabular}{|c|c|c|c|c|c|c|c|}
\hline & United States & Euro area & United Kingdom & Japan & Germany & France & Italy \\
\hline Constant & 0.006 & 0.022 & 0.002 & 0.003 & & 0.002 & \\
\hline $\operatorname{DLGDP}(-1)$ & & 0.516 & 0.584 & 0.238 & 0.402 & & 0.458 \\
\hline DLGDP(-2) & & & & -0.396 & & & \\
\hline DLGDP(-3) & & & & -0.274 & & & \\
\hline DLGDP(-4) & & & & -0.251 & & & \\
\hline DLWPOIL(-1) & & 0.012 & & & 0.034 & & 0.010 \\
\hline DLWPOIL(-2) & & -0.010 & -0.009 & & -0.024 & -0.012 & -0.019 \\
\hline DLED(-1) & & -0.003 & & & & 0.113 & \\
\hline $\operatorname{DLED}(-2)$ & & -0.088 & & & & & \\
\hline DFISC(-1) & & -0.002 & & 0.008 & & & \\
\hline DFISC(-2) & & 0.006 & & & & & \\
\hline DFISC(-3) & & -0.005 & & & & & \\
\hline $\operatorname{FCIP}(-1)$ & 0.176 & 0.161 & 0.156 & 0.341 & & 0.271 & 0.117 \\
\hline $\mathrm{FCIP}(-2)$ & & & -0.112 & -0.383 & & -0.271 & \\
\hline $\operatorname{FCIP}(-3)$ & & & & 0.478 & 0.311 & 0.110 & \\
\hline $\mathrm{FCIP}(-4)$ & & & & -0.417 & -0.268 & & \\
\hline \multicolumn{8}{|l|}{ Memorandum } \\
\hline $\begin{array}{l}\text { GDP level effect of a unit change in } \\
\mathrm{FCl}, \%{ }^{1}\end{array}$ & 0.18 & 0.33 & 0.11 & -0.06 & 0.09 & 0.11 & 0.21 \\
\hline $\mathrm{F}$ test for omission of $\mathrm{FCl}(\mathrm{p}$-value) & 0.000 & 0.001 & 0.039 & 0.000 & 0.009 & 0.000 & 0.010 \\
\hline
\end{tabular}

1. A percent change in the GDP level after 6 quarters following a temporary increase in the $\mathrm{FCl}$ by 1 unit during one quarter.

Note: The dependent variable is the log difference in real GDP. LGDP is log real GDP level; LWPOIL is log of oil prices; LED is log of external demand; FISC is the fiscal balance-to-GDP ratio; and DFCIP and FCIP are the difference and level of the FCI.

Source: Authors' calculations. 


\section{Suggested further work}

For both the FCI's created from the country-specific and the panel estimations the parameter estimates are of central importance as they are then used in creation of the weights, as a result two clear problems are apparent. First, data availability and short samples will make it less likely that the parameters from regressions are robust, directly affecting the reliability of the FCI. Second, both regression methods rely on a small number of proxy variables to describe financial variables. It is entirely possible that a different set of variables encompassing alternative elements of the financial sector could lead to alternative implications of the state of financial conditions.

An alternative way to think of financial conditions would be as an unobservable latent variable, or rather a broad concept that underpins financial conditions. There are two commonly used methods within the literature that approach the creation of an FCI in such a way: principal component analysis (PCA) and dynamic factor model (DFM).

Both methods utilise large sets of financial variables, which are assumed to share common co-movements. From this, the underlying unobservable variable can be extracted. As these methods condense large number of variables into a smaller set, the problems associated with the choice of proxies is avoided. Also, this should diminish the effect from any idiosyncratic movements in series used to create the FCI. Additionally, updating the factor loadings in both methods can be undertaken in a timely manner, since indicators of economic activity published at lower frequencies are not required.

An extension to the PCA methodology is to use DFM, where the factor loadings of the data onto the unobservable latent variables are estimated through a state space system either via Bayesian methods or the expectation maximisation algorithm. While, DFM is computationally more expensive than simple PCA it is also more flexible since the Kalman filter algorithm can accommodate missing data in a straightforward manner.

Van Roye (2011) creates a financial market stress index for Germany and the euro area using this methodology, arguing that the resulting index adequately captures periods of financial stress. Furthermore, he shows that the index has predictive power for the real economy, as its inclusion increases the out-of-sample forecasting accuracy in a small Bayesian VAR across all analysed forecast horizons. Brave and Butters (2012) further highlight the usefulness of this method. They show that National Financial Conditions Index of the Federal Reserve Bank of Chicago, has significant predictive power in identifying episodes of financial stress up to a year ahead.

As noted in Angelopoulou et al. (2013), analysing the factor loadings in order to observe patterns helps interpret developments in financial conditions. This, however, does not necessarily translate into an easily definable narrative for the implications for the real economy. Brave and Butters (2012) provide an innovative alternative, they show that it is possible to decompose the main index into sub-indices while still retaining its structure. They do this guided by the data to provide an index for risk, leverage and credit. As such, this begins to bridge the gap between an empirical study and the theoretical underpinnings associated with mechanisms that transmit from financial markets to the real economy and allow one to identify and observe such transmission mechanisms. 


\section{Conclusions}

The addition of the period of the financial crisis period has made radical changes to the OECD original results of the FCI estimation for the United States, the United Kingdom, the euro area and Japan. Country-specific estimates provide a number of wrong signs and insignificant coefficients. We find in general that the panel (and NiGEM) based FCIs are more satisfactory. Even with the panel, there are some indications from Granger Causality tests that the FCIs for some countries are not strong predictors of GDP, although all are significant in multiple regressions for GDP growth. Furthermore, a promising avenue for further research is the dynamic factor/principal components approach. This is less satisfactory in terms of "story telling" given the number of variables likely to be involved, but the approach of Brave and Butters (2010) may reduce this difficulty. 


\section{REFERENCES}

Angelopoulou, E., H. Balfoussia and H. Gibson (2013), "Building a Financial Conditions Index for the Euro Area and Selected Euro Area Countries - What does it Tell Us About the Crisis?", ECB Working Paper Series, No. 1541, May.

Barrell, R., B. Becker, J. Byrne, S. Gottschalk, A.I. Hurst and D. van Welsum (2004), "Macroeconomic Policy in Europe: Experiments with Monetary Responses and Fiscal Impulses", Economic Modelling, Vol. 21, pp. 877-931.

Barrell, R. and E. P. Davis (2008), "The evolution of the financial crisis of 2007-8", National Institute Economic Review, Vol. 206, pp. 5-14.

Barrell, R., Davis, E., Fic, T., Holland, D., Kirby, S., Liadze, I., (2009) “Optimal regulation of bank capital and liquidity: how to calibrate new international standards", Financial Services Authority Occasional Paper, No. OP38.

Barrell, R., D. Delannoy and D. Holland (2011), "Monetary Policy, Output Growth and Oil Prices", National Institute Economic Review, Vol. 215, pp. F37-F43.

Barrell, R., K. Dury, A.I. Hurst and N. Pain (2001), "Modelling the World Economy: The NIESR Model NiGEM", presented at an ENEPRI workshop, Paris: July 2001.

Barrell, R. and J. Sefton (1997), "Fiscal Policy and the Maastricht Solvency Criteria", The Manchester School, Vol. 65, pp. 259-279.

Beaton, K., R. Lalonde and C. Luu (2009), "A Financial Conditions Index for the United States”, Bank of Canada Discussion Papers, No. 2009-11.

Bernanke, B. and M. Gertler (1995), "Inside the Black Box: The Credit Channel of Monetary Policy Transmission", Journal of Economic Perspectives, Vol. 9, pp. 27-48.

Brave, S. and R. A. Butters (2012), "Diagnosing the financial system: Financial conditions and financial stress," International Journal of Central Banking, Vol. 8, pp. 191-239.

Cuaresma, J. C., E. Gnan and D. Ritzberger-Grünwald (2003), "The term structure as a predictor of real activity and inflation in the euro area: A reassessment", BIS Papers, No. 22, Bank for International Settlements, Basel.

Darracq Paries, M., L. Maurin and D. Moccero (2014), "Financial conditions index and credit supply shocks for the euro area", ECB Working Papers, No. 1644.

Davis, E. P. and G. Fagan (1997), "Are financial spreads useful indicators of future inflation and output growth in EU countries?”, Journal of Applied Econometrics, Vol. 12, pp. 701-714.

Davis, E. P. and S. G. B. Henry (1994), "The use of financial spreads as indicator variables: Evidence for the U.K. and Germany", IMF Working Papers, No. 94/31.

Driver, R. (2007), “The Bank of England Credit Conditions Survey”, Bank of England Quarterly Bulletin, Vol. 47, No. 3, pp. 389-401. 
Dudley, W. and J. Hatzius (2000), "The Goldman Sachs Financial Conditions Index: The Right Tool for a New Monetary Policy Regime”, Goldman Sachs Global Economics Paper, No. 44.

Dumitrescu, E.-I. and C. Hurlin (2012), "Testing for Granger Non-causality in Heterogeneous Panels", Economic Modelling, Vol. 29, pp. 1450-1460.

Gauthier, C., C. Graham and Y. Liu. (2004), "Financial Conditions Indexes for Canada." Bank of Canada Working Papers, No. 2004-22.

Goodhart, C. and B. Hofmann (2001), "Asset Prices, Financial Conditions, and the Transmission of Monetary Policy", Paper prepared for the Conference on Asset Prices, Exchange Rates, and Monetary Policy, Stanford University, 2-3 March.

Guichard, S. and D. Turner (2008), "Quantifying the Effect of Financial Conditions on US Activity", OECD Economics Department Working Papers, No. 635, OECD Publishing, Paris.

Guichard, S., D. Haugh and D. Turner (2009), "Quantifying the Effect of Financial Conditions in the Euro Area, Japan, United Kingdom and United States", OECD Economics Department Working Papers, No. 677, OECD Publishing, Paris.

Hansen, J. (2006), “A Risk-Index for Euro-Denominated Assets”, Danmarks Nationalbank Working Papers, No. 36.

Hatzius, J., P. Hooper, F. Mishkin, K. Schoenholtz and M. Watson (2010), "Financial Conditions Indexes: A Fresh Look After the Financial Crisis", NBER Working Paper Series, No. 16150.

Hollo, D., M. Kremer and M. Lo Duca (2012), "CISS - A Composite Indicator of Systemic Stress in the Financial System”, ECB Working Paper Series, No. 1426, March.

Hooper, P., T. Mayer and T. Slok (2007), "Financial Conditions: Central Banks Still Ahead of the Markets", Global Economic Perspectives, June 11, Deutsche Bank.

Kirby, S. and J. Meaning (2014), "Exchange rate pass-through: A view from a global structural model", National Institute Economic Review, No. 230, pp. F59-F64.

Massimiliano, M. and A. Musso (2011), "The reliability of real-time estimates of the euro area output gap", Economic Modelling, Vol. 28, pp. 1842-56.

Matheson, T. (2011), "Financial Condition Index for the United States and Euro Area", IMF Working Papers, No. WP/11/93.

Mayes, D. and M. Virén (2001), "Financial Conditions Indexes", Bank of Finland Discussion Papers, No. $17 / 2001$.

Montagnoli, O. and A. Napolitano (2004), "Financial Condition Index and interest rate settings: A comparative analysis", University of Naples Working Papers, No. 8.2005.

Murray, J. (2014), “Output gap measurement: Judgement and uncertainty", Office for Budget Responsibility Working Papers, No. 5.

Orphanides, A. and S. van Norden (2002), "The unreliability of output-gap estimates in real time", The Review of Economics and Statistics, Vol. 84, pp. 569-583. 
Pesaran, M. H. and Y. Shin (1998), "Generalized impulse response analysis in linear multivariate models", Economics Letters, Vol. 58, pp. 17-29.

Schreft, S. L. and R. E. Owens (1991), "Survey evidence of tighter credit conditions: What does it mean?", Federal Reserve of Richmond Economic Review, March/April, pp. 29-34.

Swiston, A. (2008), "A U.S. Financial Conditions Index: Putting Credit Where Credit is Due”, IMF Working Papers, No. 08/161.

van Roye, B. (2011), "Financial Stress and Economic Activity in Germany and the Euro Area", Kiel Institute for the World Economy Working Papers, No. 1743, Kiel.

Wheelock, D. C. and M. E. Wohar (2009), "Can the Term Spread Predict Output Growth and Recessions? A Survey of the Literature", Federal Reserve Bank of St. Louis Review, September/October, 91 (5, Part 1), pp. 419-40. 
ECO/WKP(2016)59

\section{APPENDIX 1. SUMMARY OF WORK ON FCIS}

\begin{tabular}{|c|c|c|c|c|}
\hline Study & Countries & Financial variables & Method & Comments \\
\hline $\begin{array}{l}\text { Dudley and } \\
\text { Hatzius } \\
(2000)\end{array}$ & United States & Stock market cap/GDP & $\begin{array}{l}\text { Using weights based on } \\
\text { GDP effects from Fed's } \\
\text { macro model }\end{array}$ & \\
\hline $\begin{array}{l}\text { Goodhart } \\
\text { and } \\
\text { Hofmann } \\
\text { (2001) }\end{array}$ & G7 individually & $\begin{array}{l}\text { Real house prices, real US equity } \\
\text { prices and US high-yield bond spread }\end{array}$ & Reduced form and VARs & $\begin{array}{l}\text { House prices } \\
\text { better indicator } \\
\text { than stock prices }\end{array}$ \\
\hline $\begin{array}{l}\text { Gauthier et } \\
\text { al. (2004) }\end{array}$ & Canada & $\begin{array}{l}\text { Real } 90 \text {-day commercial paper rate, } \\
\text { Real } 10 \text {-year Government of Canada } \\
\text { bond rate, Real C- } 6 \text { exchange rate, } \\
\text { Real housing price index, Real S\&P } \\
500 \text { stock index, U.S. high-yield risk } \\
\text { spread, in VAR also Real TSX } \\
\text { composite index }\end{array}$ & $\begin{array}{l}\text { Reduced form, VAR and } \\
\text { factor analysis }\end{array}$ & $\begin{array}{l}\text { Reduced form } \\
\text { predicts best } \\
\text { over } 1 \text { year and } \\
\text { VAR over } 1-2 \\
\text { years }\end{array}$ \\
\hline $\begin{array}{l}\text { Mayes and } \\
\text { Viren } \\
(2001)\end{array}$ & $\begin{array}{l}11 \text { European } \\
\text { countries }\end{array}$ & $\begin{array}{l}\text { Real house prices and real equity } \\
\text { prices }\end{array}$ & Reduced form estimates & $\begin{array}{l}\text { House prices } \\
\text { better indicator } \\
\text { than stock prices }\end{array}$ \\
\hline $\begin{array}{l}\text { Swiston } \\
(2008)\end{array}$ & United States & $\begin{array}{l}\text { Lending standards, corporate bond } \\
\text { yields, equity prices and exchange } \\
\text { rate }\end{array}$ & VAR estimates & $\begin{array}{l}\text { Lending survey } \\
\text { most crucial }\end{array}$ \\
\hline $\begin{array}{l}\text { Guichard } \\
\text { and Turner } \\
(2008)\end{array}$ & United States & $\begin{array}{l}\text { High-yield bond spread, lending } \\
\text { standards, real exchange rate and } \\
\text { stock market capitalisation }\end{array}$ & $\begin{array}{l}\text { Reduced form, partly } \\
\text { based on a macro } \\
\text { model, and VAR } \\
\text { compared }\end{array}$ & $\begin{array}{l}\text { Basis of current } \\
\text { paper }\end{array}$ \\
\hline $\begin{array}{l}\text { Guichard et } \\
\text { al. (2009) }\end{array}$ & $\begin{array}{l}\text { United States, } \\
\text { United } \\
\text { Kingdom, } \\
\text { Japan and euro } \\
\text { area }\end{array}$ & $\begin{array}{l}\text { Changes in the exchange rate, short } \\
\text { and long-term interest rates, the } \\
\text { change in credit availability, corporate } \\
\text { bond spreads, and household } \\
\text { financial and housing wealth }\end{array}$ & $\begin{array}{l}\text { Calibration of the effect } \\
\text { on the output gap where } \\
\text { the United States used } \\
\text { as benchmark, VAR and } \\
\text { estimated reduced form } \\
\text { compared }\end{array}$ & $\begin{array}{l}\text { Extension of } \\
\text { monetary } \\
\text { conditions } \\
\text { indices }\end{array}$ \\
\hline $\begin{array}{l}\text { Beaton et } \\
\text { al. (2009) }\end{array}$ & United States & $\begin{array}{l}\text { Real commercial paper rate, } \\
\text { business borrowing spread, lending } \\
\text { standard for consumer spending, real } \\
\text { financial wealth }\end{array}$ & Structural VECM & $\begin{array}{l}\text { Financial } \\
\text { variables } \\
\text { account for } \\
32 \text { per cent of } \\
\text { GDP growth }\end{array}$ \\
\hline
\end{tabular}




\begin{tabular}{|c|c|c|c|c|}
\hline Study & Countries & Financial variables & Method & Comments \\
\hline $\begin{array}{l}\text { Beaton et al. } \\
(2009)\end{array}$ & $\begin{array}{l}\text { United } \\
\text { States }\end{array}$ & $\begin{array}{l}\text { Real federal funds rate, real } \\
\text { mortgage rate, real effective } \\
\text { exchange rate, lending standards for } \\
\text { consumer lending, business } \\
\text { investment in equipment, business }\end{array}$ & Macro model based & $\begin{array}{l}\text { Similar results } \\
\text { to Structural } \\
\text { VECM but } \\
\text { less volatile }\end{array}$ \\
\hline
\end{tabular}

\begin{tabular}{|c|c|c|c|}
\hline $\begin{array}{l}\text { Hatzius et al. } \\
(2010)\end{array}$ & $\begin{array}{l}\text { United } \\
\text { States }\end{array}$ & $\begin{array}{l}45 \text { variables in } 5 \text { categories (1) } \\
\text { interest rate levels and spreads, } \\
\text { (2) asset prices, (3) stock and flow } \\
\text { quantities, (4) surveys and } \\
\text { (5) second moments or risk } \\
\text { measures }\end{array}$ & $\begin{array}{l}\text { Purging of variables of } \\
\text { response to developments } \\
\text { in demand, prices and } \\
\text { monetary policy and then } \\
\text { first principal component of } \\
\text { the set of financial variables }\end{array}$ \\
\hline $\begin{array}{l}\text { Matheson } \\
\text { (2011) }\end{array}$ & $\begin{array}{l}\text { United } \\
\text { States and } \\
\text { euro area }\end{array}$ & $\begin{array}{l}\text { (1) spreads (2) prices and (3) } \\
\text { quantities }\end{array}$ & Dynamic factor model \\
\hline $\begin{array}{l}\text { von Roye } \\
(2011)\end{array}$ & $\begin{array}{l}\text { Germany } \\
\text { and euro } \\
\text { area }\end{array}$ & $\begin{array}{l}\text { Three groups of variables for banking } \\
\text { sector, securities market and FX } \\
\text { market }\end{array}$ & $\begin{array}{l}\text { First principal component of } \\
\text { the set of financial variables }\end{array}$ \\
\hline $\begin{array}{l}\text { Hollo et al. } \\
\text { (2012) }\end{array}$ & Euro area & $\begin{array}{l}\text { The composite indicator of systemic } \\
\text { stress (CISS) is built up from five } \\
\text { sub-indices } 3 \text { variables per group }\end{array}$ & $\begin{array}{l}\text { The } \mathrm{FCl} \text { is computed in two } \\
\text { steps: 1) Variables } \\
\text { aggregated; 2) The sub- } \\
\text { indices are aggregated on } \\
\text { the basis of weights which } \\
\text { reflect their time-varying } \\
\text { cross-correlation and their } \\
\text { average relative impact on } \\
\text { economic activity }\end{array}$ \\
\hline
\end{tabular}
investment in structures, mortgages and real financial wealth

\begin{tabular}{|c|c|c|c|c|}
\hline $\begin{array}{l}\text { Angelopoulou } \\
\text { et al. (2013) }\end{array}$ & $\begin{array}{l}\text { Euro area, } \\
\text { Germany, } \\
\text { Ireland, } \\
\text { Greece, } \\
\text { Portugal and } \\
\text { Spain }\end{array}$ & $\begin{array}{l}\text { Prices, quantities, surveys and a } \\
\text { volatility measure }\end{array}$ & $\begin{array}{l}\text { First three principal } \\
\text { components of the set of } \\
\text { financial variables }\end{array}$ & $\begin{array}{l}\text { No } \\
\text { differencing } \\
\text { for stationarity }\end{array}$ \\
\hline $\begin{array}{l}\text { Darracq } \\
\text { Paries et al. } \\
(2014)\end{array}$ & $\begin{array}{l}\text { Euro area, } \\
\text { Germany, } \\
\text { France, Italy } \\
\text { and Spain }\end{array}$ & $\begin{array}{l}\text { Bank lending rates, MFI loans to } \\
\text { households and NFCs, money } \\
\text { growth, spreads between } \\
\text { government bond yields of different } \\
\text { maturities, bank capital and liquidity, } \\
\text { equity and securities issuance by } \\
\text { MFIs and NFCs, bank and corporate } \\
\text { bond yields, stock market returns of } \\
\text { financial and non-financial } \\
\text { institutions, volatility in equity and } \\
\text { exchange rate markets, and } \\
\text { correlations among different financial } \\
\text { variables, among others. The foreign } \\
\text { exchange rate and the price of raw } \\
\text { materials are also included }\end{array}$ & $\begin{array}{l}\text { Purging of variables of } \\
\text { response to developments } \\
\text { in demand, prices and } \\
\text { monetary policy and then } \\
\text { first principal component of } \\
\text { the set of financial variables }\end{array}$ & $\begin{array}{l}\text { Differencing } \\
\text { for stationarity }\end{array}$ \\
\hline
\end{tabular}

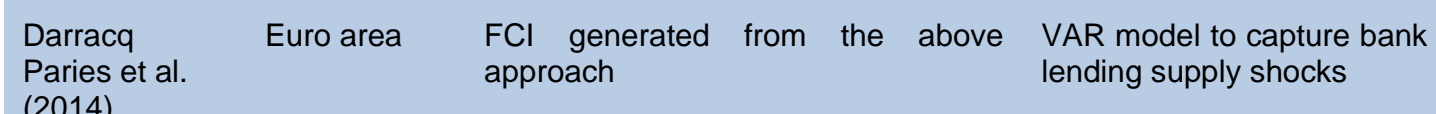


ECO/WKP(2016)59

\section{APPENDIX 2. THE NATIONAL INSTITUTE GLOBAL ECONOMETRIC MODEL (NIGEM)}

NiGEM is a large estimated quarterly model of the United Kingdom and the world economies. The model is intended to capture the key features of the major world economies. It is theoretically coherent and quantified by means of empirical estimation over recent historical experience. It provides a plausible benchmark for estimating the effects on the economy of different policy decisions as well as other types of shocks. Recent examples of such work includes the simulated effect of changes to bank regulation on the wider UK economy (Barrell et al., 2009) and the likely impact of the recent rise in oil prices (Barrell et al., 2011). In contrast to many small theoretical models of the economy, its complete specification ensures that important features of the economy are not omitted from the analysis.

It is set in what is essentially a New-Keynesian framework where agents are forward looking, but nominal rigidities, namely sticky prices and adjustment costs, slow down the adjustment to the long-run equilibrium. It includes complete demand and supply sides, as well as extensive monetary and financial sectors. Domestic demand, aggregate supply, and the external sector are linked through the wage-price system, income and wealth, the financial sector, the government sector, and competitiveness. The external sector links the domestic economy to the rest of the world. The theoretical structure and the relevant simulation properties of NiGEM are described in detail in Barrell et al. $(2001,2004){ }^{6}$

6. More details are available at: $\underline{\text { https://nimodel.niesr.ac.uk/. }}$ 